Shevchenko Olena

Doctor of Science in Social Communications,

Professor of the Department of Information

Activity and Media Communications

Odessa National Polytechnic University

ORCID 000-003-2313-5939

shevchenko_o.v@opu.ua

\title{
UKRAINIAN FOLK EMBROIDERY AS A WAY OF IDENTIFICATION AND COMMUNICATIVE INTERACTION OF THE UKRAINIAN PEOPLE IN MODERN CONDITIONS
}

The purpose of the work is to reveal the issue of the influence of Ukrainian embroidery as an artistic phenomenon of the Ukrainian clothes on the formation of the consciousness of the Ukrainian people, on its communicative interaction, consolidation and unification in the current conditions of development of the Ukrainian state. The research methodology is associated with the use of theoretical analysis and synthesis methods. Scientific novelty. The article deals with the issues of the influence of Ukrainian embroidery on the self-identification of the Ukrainian people, its interaction, aimed at unification; ways of forming a national identity on the basis of Ukrainian ritual are analyzed; the distinctive features of Ukrainian clothes, symbolic images, embroidered ornaments and their manifestation in the mentality and national identity of the Ukrainian people are characterized. Conclusions. Ukrainian clothing is a work of art, where embroidery is an inalienable attribute and a symbol of Ukrainian folk culture, and a regulator of ethno-cultural information. The Ukrainian shirt is the main functional and symbolic element of the women's dress and attests to the degree of development and the specifics of the communicative behavior of Ukrainians, its use for social status, membership of a particular social stratum, its close connection with ethnic stereotypes, and moral norms of conduct.

Keywords: Ukrainian embroidery, Ukrainian clothing, clothes, Ukrainian nation, technique of embroidery, ornament, symbols, self-identification of Ukrainians, Ukrainian culture.

Шевченко Олена Василівна, доктор наук з соціальних комунікацій, професор кафедри інформаційної діяльності та медіа-комунікацій Одеського національного політехнічного університету

Українська народна вишивка як засіб ідентифікації та комунікативного взаємодій українського народу в сучасних умовах

Мета роботи. Розкрити питання впливу української вишивки як художнього явища українського вбрання на фрормування самосвідомості українського народу, на його комунікативну взаємодію, консолідацію і об'єднання в сучасних умовах розвитку Української держави. Методологія дослідження пов'язується з використанням методів теоретичного аналізу та синтезу. Наукова новизна. У статті розглянуто питання впливу української вишивки на самоідентифікацію українського народу, його взаємодію, спрямовані на об'єднання; проаналізовано шляхи формування національної ідентичності на основі української обрядовості; розкрито відмінності, характерні регіональні особливості одягу українців, символічних зображень, орнаментів вишивок і їх вияв у ментальності та національній ідентичності українського народу. Висновки. Українське вбрання - це витвір мистецтва, де вишивка $\epsilon$ невід'ємним атрибутом і символом української народної культури, є регулятором етнокультурної інформації. Українська сорочка - основний функціональний і символічний елемент вбрання жіноцтва і засвідчують ступінь розвитку і специфіку комунікативної поведінки українців, його використання при соціальному статусі, приналежність до певної соціальної верстви, його тісний зв'язок з етнічними стереотипами, моральними нормами поведінки.

Ключові слова: українська вишивка, українське вбрання, одяг, українська нація, техніка вишивки, орнамент, символи, самоідентифікація українців, українська культура.

Шевченко Елена Васильевна, доктор наук с социальных коммуникаций, професссор кафредры информационной деятельности и медиа-коммуникаций Одесского национального политехнического университета

Украинская народная вышивка как средство идентификации и коммуникативного взаимодействий украинского народа в современных условиях

Цель работы. Раскрыть вопросы влияния украинской вышивки как художественного явления украинской одежды на формирование самосознания украинского народа, его коммуникативное взаимодействие, консолидацию и объединение в современных условиях развития Украинского государства. Методология исследования связывается с использованием методов теоретического анализа и синтеза. Научная новизна. В статье рассмотрены вопросы влияния украинской вышивки на самоидентификацию украинского народа, его взаимодействие, направленные на объединение; проанализированы пути формирования национальной идентичности на основе украинских традиций; раскрыты различия, характерные региональные особенности одежды украинского народа, символические изображения, орнаменты вышивки и их проявление в ментальности и национальной идентичности украинского народа. Выводы. Украинский наряд это произведение искусства, где вышивка является неотъемлемым атрибутом и символом украинской народной культуры, является регулятором этнокультурной информации. Украинская сорочка основной функциональный и символический элемент одежды женщин и свидетельствуют о степени развития и специфике коммуникативного поведения украинского народу, его использование в социальном статусе, принадлежности к определенному социальному слою, его тесной связи с этническими стереотипами, нравственными нормами поведения.

Ключевые слова: украинская вышивка, украинский наряд, одежда, украинская нация, техника вышивки, орнамент, символы, самоидентификация украинцев, украинская культура.

(c) Shevchenko O., 2018 
Relevance of research topic. Ukrainian folk embroidery is an important artistic value that performs a communicative function. Without national self-awareness, understanding of the past and own cultural and national identity it is impossible to formulate a strategy, priorities, the basis of stimulating of the development of Ukrainian society. In today's conditions, it is becoming increasingly important to preserve the traditions of the Ukrainian people, its national identification and identity.

The purpose of the study is to reveal the issue of the influence of Ukrainian embroidery as an artistic phenomenon of Ukrainian dress on formation self-consciousness of the Ukrainian people, on its communicative interaction, consolidation and association in the modern conditions of development of the Ukrainian state.

Presentation of basic materials. The defining feature of Ukrainianity is the awareness of their own identity, unity in the linguistic, cultural, and mental dimensions. However, there were de-Ukrainianization and the reduction of the proportion of Ukrainians in the Soviet era, with the Russians as a dominant minority, but politically dominant. The Russians as a dominant minority were concentrated in cities, administrative, industrial, scientific and educational centers. The identification of the individual at the national level is closely linked to the political processes, and the policy of Russia with the assertion that Ukrainians and Russians are one ethnic group was the main way of destroying Ukrainian identity [12].

Different aspects of national identity are concentrated in the publications of V. Serhiychuk, O. Zadorozhny. The significance of Christian ceremonies for the ethno-national development of Ukrainians is considered in the researches of Y. Katrina. The origins of folk ceremonies are explored by S. Cherepanova. The role of the church in preserving the ritual and culture is revealed by B. Bileuy. Important information on regional and local stylistic abolition of techniques, color scheme, embroidery designs of Bukovinsky and Western Podillya is given in the research by R. Zakharchuk-Chugai «Folk Embroidery of Western Ukraine of the 19th-20th centuries».

The researches of O. Voropaja, O. Vlasyuka, L. Ogneva, S. Gayova, O. Kosmine, S. Latansky, S. Sidorovich, B. Sushevsky, Y. Melnychuk, O. Katsan, Yu. Melnychuk and others have a big scientific value. They are devoted to the detailed consideration of issues of national clothing, Ukrainian costume, weaving in the formation of a distinctive culture, identification of Ukrainians as a people, studying its ethno-culture.

Referring to O. Redko's point of view that self-consciousness of the person is expressed in his selfidentification (national), then an important component of human spirituality is the national consciousness, which includes cultural and historical memory as an image of the past, present and future [10]. The amulets accompanied old Ukrainians in their lives - Easter crayons, a wedding towel, a scarf, an embroidered shirt, a wedding ring, and others. [1]. The main function of embroidery is decoration of clothes and fabrics for the purpose of equipment of living conditions. The material base for embroidering was home-made woolen, linen, hemp fabric [14, 360-361].

The Ukrainian clothes are classified according to various features, among which are: the region of existence (Polissya, Podillya, Poltavshchina, Volyn, etc.), the way of wearing (femoral, shoulder, upper, lower), croup (bumpy, deaf, solid, crocheted, cut), material manufacturing (home-made, factory, linen, wool), coloring (monochrome, polychrome), ritual (family, seasonal), gender (male, female) [7]. The complex of traditional Ukrainian clothes consists of several components - shoulder straps, hats, shoes and jewelry. The main component of the national dress of Ukrainians is a shirt. The Ukrainian shirt had a lot of name variations - «koshulya», «morshinka», "oplich», "prisbirka», «rubatka», «sorocheuna», «hlopyanka», "chumachka», featured a cut, but it was combined with embroidery.

Women's shirt acted as a symbol of the continuation of life. Woman who had a lot of children loaned her shirt to a woman who could not get pregnant. The decoration of shirts shows the age change of women. The brightness and openness of the colors highlighted the costume of the «marriageable» girl, but older women's clothing had more reserved colors [6; 13]. Embroidered shirts were passed from generation to generation as family helixes. Embroidered symbols (teeth, rhombuses, zigzags) symbolized land and water, people and animals, birds, plants and had the goal of protecting the human soul from destruction [1].

The shirt, as the closest to the body element of the garment, was identified with the magic power that exists in the human body, therefore the embroidery was symbolically significant as a protector of man and its symbolic substitute [6]. Men wore a sleeveless shirt, the upper garment was a retinue, a shroud, a coat with a hood [1]. Wedding shirts have always been divorced - crested from one whole piece of canvas at full height, which had the highest ritual status in the ceremonial culture of the Ukrainian people [6; 8]. The wedding shirt that the young girl sewed for her bridegroom symbolized his «new birth», when changing his social status. The symbolism of embroidered wedding shirts contained the wishes of the good of family life. Everyday shirts practically were not embroidered. They used a coarse, unbleached fabric for their sewing $[6,127]$.

The symbolism reflected the ancient archaic representations of Ukrainians about the "cult of the earth" and their native home. The mentality of the Ukrainian people was formed and evolved under the influence of the natural environment, traditions, and determined the way of life. The diversity of regional differences gradually replaced the national consciousness on the basis of the agricultural type of the nature of the people, the idea of the value of the earth, the essence of the Mother Earth. Dominant ideas of Ukrainian communication have the closest connection with nature through the maternal origin, its priority, which is 
manifested in the features of softness, lyricism; tolerance, kindness, respect for elders in the social environment [5, 43, 50 - 57].

The main age identifier in Ukrainian women's clothing was hats, which consisted of two components: nested (plain) and stitched. Hat is a piece of cloth tied in various ways to the head over a sewn headdress (cap, cape, captcha), which include marks - the gender marker. Capes were made of expensive fabrics, decorated with silk or velvet ribbons. The wreath was considered a maiden headdress. For example, in Poltava and Kyiv regions there were wreaths made of silk tapes, assembled in different ways: in the form of sockets; tapes collected in folds [8, 120].

In addition, there are interesting ways to tie a scarf in identifying the age difference between Ukrainian women. For instance, women tied a shawl behind, the girls - «under the beard», the young lady - «Turkish way» with small nodes. In Volyn, women wore linen handkerchiefs with ornaments, which were knotted behind and called it «sickle» [1]. The wipes were woven from white and red linen yarn, the pattern was both checkered and striped.

Men wore winter (made of wool of a young ram of black or gray colour), hats and summer straw hats. Some regions had their own features: for example, cylindrical caps of cloth with round or square top were used in Polissya and Volyn, and felt hats in Western Ukraine. The festive hats were decorated with several rows of polychrome beaded ribbons, the top was decorated with colored duck feathers, colored woolen balls [6, 131].

In addition to shirts, hats, outwear, the clothes of Ukrainian girls were distinguished by an apron in contrast to women's clothes. An apron in the girl's clothes testified that the girl became a grown-up girl and could go to evening parties and girlish parties. Lots of coral, amber, pearls, and necklaces created a complex composition that supplemented the outfit and was a kind of protective barrier between the outside world and $\operatorname{man}[6 ; 11]$.

One can agree with the viewpoint of $\mathrm{V}$. Serhiychuk that the creation of the Ukrainian nation was under the influence of agriculture, which was facilitated by the natural and climatic conditions that provided autochthonous inhabitants with the necessities of settled life, since the Ukrainian ethnic community consisted of land associations, was based on awareness of belonging to the native land, the land of ancestors [10]. Considering $O$. Dedusha's point of view, national identity as a complex of representations about one's own nation and its connections with such formations is closely linked to imago (from the Latin «imago» image). Problems of imago were first raised by M. Kostomarov and V. Antonovich, who described differences in the mentality and identity of Russians, Poles and Ukrainians (the image of a Ukrainian as a Malorossian in the Russian Empire and an eastern Masovian for the Poles) [2, 70; 4].

The novelty of the study consists in examining in detail the impact of Ukrainian embroidery on the self-identification of the Ukrainian people, its interaction, aimed at unification; analysis of ways of formation of national identity on the base of Ukrainian ritual; revealing differences, typical regional features of Ukrainian clothes, symbolic images, embroidery ornaments and their manifestation in the mentality and national identity of the Ukrainian people.

It should be noted that national identity in the process of addressing consciousness is an image and a stereotype related to the spiritual culture, material phenomena, and other connections, which explains their understanding of ethnic stereotypes received from the environment and designed on the base of impressions, the experience of establishing ethnicities communities [3]. According to O. S. Redko, there is the system of traditions, customs for shaping the worldview consciousness and valuable orientations of young people, giving social experience, the achievements of previous generations [9].

Conclusions. According to the study, one can conclude that: 1) the image of the Ukrainian state is inextricably linked with Ukrainian clothing, embroidery, decoration techniques, ornamentation, composition, color, typical to every region of the Ukrainian state, which has been changing for centuries, however, the rules of traditional wearing of clothing in the context of communicative behavior are stable, the manifestation of the essence of the people in the process of communication and the emergence of communicative interaction and the formation of stereotypes of spiritual culture; 2) Ukrainian embroidery is an inalienable attribute and a symbol of Ukrainian folk culture and a regulator of ethno-cultural information; 2) among Ukrainian clothes, the Ukrainian shirt is the main functional and symbolic element of women's dress and indicates the degree of development and specifics of communicative behavior of Ukrainians, their use for social status, membership of a certain social stratum, the connection with ethnic stereotypes, and moral norms of conduct.

Systematization, assessment, scientific re-thinking of embroidery as an artistic phenomenon, national dress, its decoration, accentuation of the dominant color and the communicative influence of the heredity of the phenomena of spiritual and material cultures on the formation of national consciousness of the Ukrainian people requires the further study.

\section{תimepamypa}

1. Гуркіна Г. О., О.В.Сердюк. Традиції та звичаї українців. Харків: Торсінг Плюс, 2010. 95 с.

2. Дєдуш О. Національна ідентичність крізь призму імагології . Народна творчість та етнологія. 2017. № 1. C. $68-71$.

3. Касьянов Г. Націоналізація історії та образу іншого. Критика. 2006. № 9-10. С. 22-25. 
4. Куций І. Імагологія як стратегія дослідження цивілізаційних образів в українській історіографії. Наукові записки Тернопільського нац. педагогічного ун-ту ім. В. Гнатюка. 2014. Вип. 2. Ч.1. С. 240-247.

5. Мазуркевич О. П., Дячук В. П. Звичаєві норми етикету у традиційній культурі українців. Київ: Ліра, 2015. 217 c.

6. Народна культура українців: життєвий шлях людини: історико- етнологічне дослідження: у 5 т. / під заг. ред. М. Гримич. Київ: Дуліби, 2010.Т. 2. Молодь. Молодість. Молодіжна субкультура. 2010. 567 с.

7. Народна культура українців: життєвий шлях людини: історико- етнологічне дослідження: у 5 т. / під заг. ред. М. Гримич. Київ: Дуліби, 2012. Т. 3. Зрілість. Жіноцтво. Жіноча субкультура. 2012. 480 с.

8. Народна культура українців: життєвий шлях людини: історико- етнологічне дослідження: у 5 т. / під заг. ред. М. Гримич. Київ: Дуліби, 2012. Т. 4. Зрілість. Чоловіки. Чоловіча субкультура. 2013. 584 с.

9. Редько О. С. Українська вишивка одна зі складових естетичного виховання. Проблеми фрілософрії освіти та виховання особистості. 2015. С. $287-297$.

10. Сергійчук В. Шляхи формування української ідентичності і державності і автохтонне хліборобство та глибока духовність. Народна творчість та етнологія. 2017 . № 4. С. 26 - 39.

11. Скляр В. Демографрічний потенціал та етномовний склад населення Донбасу (підпорядковані Україні та окуповані терени) / В. Скляр // Народна творчість та етнологія. - 2017 .- № 3. - С. 24-35.

12. Скляр В. Сучасна українська ідентичність як наслідок бездержавного минулого. Народна творчість та етнологія. 2015. № 1. С. 28-35.

13. Сушевський Б. Поезій на білім полотні. Слово Просвіти. 2012. 11 квіт. С. 14.

14. Українське народознавство / під заг. ред. С. П. Павлюка. 3-тє вид. випр. Київ: Знання, 2006. 567 с.

\section{References} Ukrainian].

1. Gurkina, G.O., Serdyuk, O. V. (2010). Traditions and customs of Ukrainians.. Kharkiv: Thorsing Plus. [in

2. Dedush, O. (2017). National identity through the prism of imago. Folk art and ethnology, 1, 68-71. [in Ukrainian].

3. Kasyanov, G. (2006). Nationalization of history and the other Image. Criticism. Kyiv, 9-10, 22-25. [in Ukrainian].

4. Kustiy, I. (2014). Imagology as a strategy for the study of civilizational images in Ukrainian historiography. Scientific Notes of Ternopil National University. pedagogical university. V. Hnatyuk. Vip. 2. Part 1. (pp. 240-247). [in Ukrainian]. Ukrainian].

5. Mazurkevich, O. P. (2015). Common rules of etiquette in the traditional Ukrainian culture. Kyiv: Lira. [in

6. Folk culture of Ukrainians: the human way of life: historical and ethnological research (2010) in 5 volumes. Kyiv: Duliby. (Vol. 2). Youth. Youth. Youth subculture. [in Ukrainian].

7. Folk culture of Ukrainians: human way of life: historical and ethnological research (2012) in 5 volumes. Kyiv: Duliby. (Vol. 3). Maturity. Womenfolk. Female subculture. [in Ukrainian].

8. Folk culture of Ukrainians: human way of life: historical and ethnological research (2013) in 5 volumes. Kyiv: Duliby. (Vol. 4). Maturity. Men Men's Subculture. [in Ukrainian].

9. Redko, O. S. (2015). Ukrainian embroidery is one of the components of aesthetic education . Problems of the philosophy of education and personality education, $287-297)$. [in Ukrainian].

10. Sergiychuk, V. (2017). Ways of formation of Ukrainian identity and statehood and autochthonous farming and deep spirituality. Folk art and ethnology, 4, 26-39. [in Ukrainian].

11. Sklyar, V. (2017). Demographic potential and the ethno-speaking composition of the Donbas population (subordinated to Ukraine and occupied territories). Folk art and ethnology, 3, 24-35. [in Ukrainian].

12. Sklyar, B. (2015). Contemporary Ukrainian Identity as a Consequence of the Stateless Past. Folk Art and Ethnology, 1, 28-35. [in Ukrainian].

13. Sushevsky, B. (2012). Poetry on a white canvas. Word of Enlightenment. Apr. 11, 14. [in Ukrainian].

14. Ukrainian ethnography (2006). Kyiv: Knowledge. [in Ukrainian].

Стаття надійшла до редакції 14.08.2018 p. 